\section{Kinetics of the Oxidation of Acetaldehyde by Manganese(III) Sulphate}

\section{S. Murdia, R. Shanker, and G. V. BAKORE}

Chemistry Department, University of Udaipur, India

(Z. Naturforsch. 29 b, 691-693 [1974]; received July 11, 1974)

Acetaldehyde, Manganese(III)-sulphate, Activation parameters

Oxidation of acetaldehyde with manganese(III)sulphate is first order with respect to acetaldehyde and the oxidant. The rate is independent of acidity $(2.0>$ $\left[\mathrm{H}^{+}\right]<5.0 \mathrm{M}$ and initial [Mn(II)]. Formaldehyde is one of the products of oxidation. Activation parameters for the reaction have been evaluated. The rate of enolisation under similar conditions is less than the rate of oxidation. A mechanism involving a direct attack on the aldehyde by $\mathrm{Mn}$ (III) has been suggested.

DRUMmond and WATERS ${ }^{1}$ have investigated the oxidation of propionaldehyde and $n$-butyraldehyde by manganese(III)-pyrophosphate. They found that oxidation of both these aldehydes are fairly rapid reactions. The rate of oxidation is proportional to the concentration of both the aldehydes and that of hydrogen ions but is independent of Mn(III)pyrophosphate. The latter observation has been taken as an evidence to suggest that oxidation proceeds via enolisation. This is further supported by the fact that non-enolisable aldehydes like formaldehyde and chloral do not react with Mn(III)pyrophosphate.

Although formaldehyde is unreactive towards Mn(III)-pyrophosphate it is oxidised by Mn(III)sulphate under acidic conditions ${ }^{2}$. It has been demonstrated earlier by LITTLER $^{3}$ that Mn(III)sulphate is able to oxidise ketones much faster than

Requests for reprints should be sent to Prof. G. V. BAKORE, Department of Chemistry, University of Udaipur (M. B. College) Udaipur. 313001, India. they undergo enolisation. Oxidation of aliphatic aldehydes has not received much attention. Kinetics of the oxidation of acetaldehyde was, therefore, undertaken the results of which are reported here.

\section{Experimental}

Acetaldehyde (B. D. H., A. R.) was used after fractionation and its purity checked by its boiling point. Mn(III)-sulphate was prepared by the method described by VOGEL ${ }^{4}$. The reaction was carried out at $30 \pm 0.02{ }^{\circ} \mathrm{C}$ and was followed spectrophotometrically at $520 \mathrm{~nm}$ using a Hilger pattern biochem. absorptiometer. The cell tube was surrounded by a block through which thermostated water was circulated.

\section{Stoichiometry and product analysis}

One mole of acetaldehyde consumes 4 moles of the oxidant. Formaldehyde, detected by chromotropic acid test ${ }^{6}$, is one of the products of exidation. Thus, the overall reaction can be represonted as:

$$
\begin{aligned}
& \mathrm{CH}_{3} \mathrm{CHO}+4 \mathrm{Mn}^{3+}+2 \mathrm{H}_{2} \mathrm{O} \rightarrow \\
& \mathrm{HCHO}+\mathrm{HCOOH}+4 \mathrm{Mn}^{2+}+2 \mathrm{H}^{+}
\end{aligned}
$$

\section{Results and Discussion}

When the concentration of acetaldehyde is in excess (tenfold or more than [Mn(III)]), the rate at which $\mathrm{Mn}(\mathrm{III})$ disappears follows a first order rate law up to $60-70 \%$ of the reaction. Pseudo first order rate constant, $k_{1}$, is independent of the initial concentration of $\mathrm{Mn}$ (III) (cf. Table I). The order in $[\mathrm{Mn}(\mathrm{III})]$ is, therefore, one. The order with respect to aldehyde is also one (Table II). At constant ionic strength, variation of concentration of sulphuric acid from 2.0 to $5.0 \mathrm{~m}$ does not noticeably affect the rate of oxidation (Table III). Addition of $\mathrm{Mn}$ (II) has no effect on the rate. (Table IV) (cf. KEMP and WATERS $^{2}$ ). The data on the effect of temperature on the rate and activation parameters has been collected in Table V.

\section{Rate of enolisation}

Drummond and WATERs ${ }^{1}$ have concluded that oxidation of propionaldehyde and $n$-butyraldehyde by $\mathrm{Mn}(\mathrm{III})$-pyrophosphate is zero order in Mn(III)-

\begin{tabular}{|c|c|c|c|c|c|}
\hline \multicolumn{6}{|c|}{$\left[\mathrm{CH}_{3} \mathrm{CHO}\right]: 5.0 \times 10^{-3} \mathrm{M} ;\left[\mathrm{H}_{2} \mathrm{SO}_{4}\right]: 2.0 \mathrm{M}$; Temperature: $30{ }^{\circ} \mathrm{C}$} \\
\hline$[\mathrm{Mn}(\mathrm{III})] \times 10^{3}:($ moles $/$ liter $)$ & 5.0 & 6.0 & 7.0 & 8.0 & 10.0 \\
\hline $\mathrm{k}_{1} \times 10^{3}( \pm 5.0 \%) \sec ^{-1}:$ & 5.42 & 5.41 & 5.38 & 5.39 & 5.48 \\
\hline
\end{tabular}

Table I. Variation of rate with initial [Mn(III)].

Table II. Variation of rate with initial [acetaldehyde].

$[\mathrm{Mn}(\mathrm{III})]: 5.0 \times 10^{-3} \mathrm{M} ;\left[\mathrm{H}_{2} \mathrm{SO}_{4}\right]: 2.0 \mathrm{M}$; Temperature: $30{ }^{\circ} \mathrm{C}$

\begin{tabular}{lllll}
\hline [Aldehyde] $\times 10^{2}$ (moles/liter) : & 2.50 & 3.00 & 4.00 & 4.50 \\
$\mathrm{k}_{1} \times 10^{3} \mathrm{sec}^{-1}:$ & 2.75 & 3.30 & 4.24 & 4.72 \\
$\mathrm{k}_{1} /[$ aldehyde] (liter mole & & $\left.0.10 \mathrm{sec}^{-1}\right):$ \\
\hline
\end{tabular}


Table III. Dependence of rate on initial $\left[\mathrm{H}_{2} \mathrm{SO}_{4}\right]$.

\begin{tabular}{|c|c|c|c|c|c|c|}
\hline \multicolumn{7}{|c|}{$\left[\right.$ Aldehyde] $: 4.50 \times 10^{-2} \mathrm{M} ;[\mathrm{Mn}(\mathrm{III})]: 9.0 \times 10^{-3} \mathrm{M} ;$ Temp.: $30^{\circ} \mathrm{C}$} \\
\hline $\begin{array}{l}{\left[\mathrm{H}_{2} \mathrm{SO}_{4}\right]^{*} \text { (moles/liter): }} \\
\mathrm{k}_{1} \times 10^{3} \mathrm{sec}^{-1}:\end{array}$ & $\begin{array}{l}2.0 \\
3.54\end{array}$ & $\begin{array}{l}3.0 \\
3.30\end{array}$ & $\begin{array}{l}3.5 \\
3.45\end{array}$ & $\begin{array}{l}4.0 \\
3.40\end{array}$ & $\begin{array}{l}4.5 \\
3.50\end{array}$ & $\begin{array}{l}5.0 \\
3.50\end{array}$ \\
\hline
\end{tabular}

$*\left\{\left[\mathrm{H}_{2} \mathrm{SO}_{4}\right]+\left[\mathrm{NaHSO}_{4}\right]\right\}=5.0 \mathrm{M}$.

Table IV. Dependence of rate on initial [Mn(II)].

\begin{tabular}{lcccccc}
\hline \multicolumn{7}{c}{$\left[\begin{array}{l}\text { [Aldehyde }: 3.25 \times 10^{-2} \mathrm{M} ;[\mathrm{Mn}(\mathrm{III})]: 6.60 \times 10^{-3} \mathrm{M} ; \mathrm{Temp} .: 30{ }^{\circ} \mathrm{C} \\
{\left[\mathrm{H}_{2} \mathrm{SO}_{4}\right]: 2.0 \mathrm{M} ;}\end{array}\left[\mathrm{MnSO}_{4}\right]+\left[\mathrm{ZnSO}_{4}\right]\right\}: 0.50 \mathrm{M}$} \\
\hline$[\mathrm{Mn}(\mathrm{II})](\mathrm{M}):$ & 0.50 & 0.10 & 0.20 & 0.30 & 0.40 & 0.50 \\
$\mathrm{k}_{1} \times 10^{3} \mathrm{sec}^{-1}:$ & 3.50 & 3.55 & 3.51 & 3.67 & 3.50 & 3.50 \\
\hline
\end{tabular}

Table V. Temperature dependence of rate and activation parameters.

\begin{tabular}{|c|c|c|c|c|c|c|}
\hline \multicolumn{7}{|c|}{ [Aldehyde]: $3.75 \times 10^{-2} \mathrm{M} ;[\mathrm{Mn}(\mathrm{III})]: 6.0 \times 10^{-3} \mathrm{M} ;\left[\mathrm{H}_{2} \mathrm{SO}_{4}\right]: 2.0 \mathrm{M}$} \\
\hline Temperature $\left({ }^{\circ} \mathrm{A}\right)$ : & 293 & 298 & 303 & 308 & $\begin{array}{l}\Delta \mathrm{H}^{*} \\
(\mathrm{kcals} / \mathrm{mole})\end{array}$ & $\begin{array}{l}\Delta \mathrm{S}^{*} \\
\text { (e.u.) }\end{array}$ \\
\hline $\mathrm{k}_{1} \times 10^{3} \mathrm{sec}^{-1}:$ & 1.29 & 2.30 & 3.98 & 6.90 & $20.1 \pm 1.5$ & $+4.5 \pm 5.0$ \\
\hline
\end{tabular}

Table VI. Comparison of rate of oxidation with enolisation.

[Aldehyde]: $5.0 \times 10^{-2} \mathrm{M} ;[\mathrm{Mn}(\mathrm{III})]: 5.0 \times 10^{-3} \mathrm{M} ;\left[\mathrm{H}_{2} \mathrm{SO}_{4}\right]: 2.0 \mathrm{M}$; Temp.: $30^{\circ} \mathrm{C}$

Rate of enolisation (liter/mole. sec.):

$1.77 \times 10^{-6}$

Rate of oxidation (liter/mole. sec.):

$15.2 \times 10^{-6}$

pyrophosphate thus involving enolisation as the rate limiting step. This is further substantiated by the fact that non-enolisable aldehydes like formaldehyde and chloral do not react with $\mathrm{Mn}$ (III)pyrophosphate. Thus the rate of oxidation of aldehydes by $\mathrm{Mn}(\mathrm{III})$-pyrophosphate should give the rates of enolisation. The rate of enolisation was estimated by measuring the rate of oxidation by $\mathrm{Mn}(\mathrm{III})$-pyrophosphate at different initial hydrogen ion concentrations and from the rate laws. These rates were, then, used to evaluate the rate of enolisation under conditions of oxidation of acetaldehyde by $\mathrm{Mn}$ (III) sulphate. The rates of oxidation and enolisation are recorded in Table VI.

The fact that the rate of oxidation is greater than the rate of enolisation suggests that oxidation of the aldehyde by $\mathrm{Mn}(\mathrm{III})$-sulphate involves a direct attack as shown:

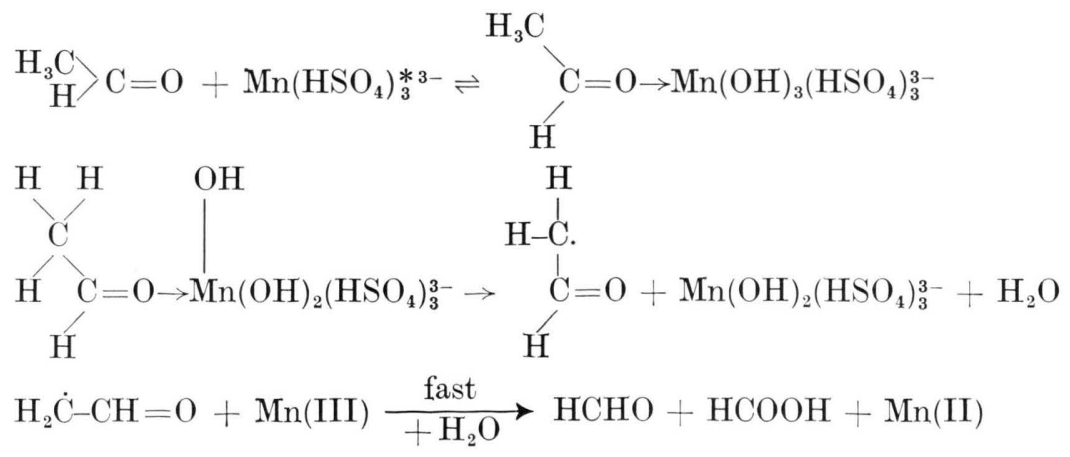

From the work of Kemp and Waters (1. c. $\left.{ }^{2}\right)$ the rate

* Under the acid conditions used here sulphuric acid of oxidation of formaldehyde is 300 times slower than that of acetaldehyde. Formic acid reacts even slower than formaldehyde. The presence of formaldehyde is, therefore, not unexpected. of $\mathrm{Mn}$ (III) to be six, the probable composition could be $\mathrm{Mn}\left(\mathrm{HSO}_{4}\right)_{2}(\mathrm{OH})_{3}^{3-}($ cf. $\mathrm{Ce}(\mathrm{IV})$ complex $)$. 
${ }^{1}$ A. Y. Drummond and W. A. Waters, J. Chem. Soc. 1953, 435.

2 T. J. KeMP and W. A. Waters, ibid. 1964, 339.

${ }^{3}$ J. S. LitTtLer, ibid. 1962, 832.

${ }^{4}$ A. I. Vogel, 'A Text Book of Quantitative Inor- ganic Analysis', p. 327, Longmans Green \& Co., London 1964

5 G. Fiegel, "Spot Tests in Organic Analysis", p. 435, Elsevier Publishing Co., Amsterdam 1966.

\section{1,2-Benzthiazolinone: Reaction with Sulphite, Cyanide, and Cyanate}

\author{
W. V. FARRAR
}

UMIST, Manchester M60 1QD, England

(Z. Naturforsch. 29 b, 693-694 [1974]; received June 18, 1974)

1,2-Benzthiazolinone, Ring enlargement

Reactions of title compound with sulphite, cyanide, and cyanate are described.

1,2-Benzthiazolinone $(\mathbf{1}, \mathrm{R}=\mathrm{H})$ is a heterocycle which undergoes many unexpected reactions. The following have not previously been described.

$1(\mathrm{R}=\mathrm{H})$ dissolves in aqueous $\mathrm{NaHSO}_{3}$ to give an addition compound, at first thought to be the Bunte salt $\left(2, \mathrm{R}=\mathrm{SO}_{3} \mathrm{Na}\right)\left(c f .{ }^{1}\right)$. This reacted as expected with cyanide ion to precipitate a substance which should have been the thiocyanato-compound $(2, \mathrm{R}=\mathrm{CN})$. This could not be so, however, since the supposed $2(\mathrm{R}=\mathrm{CN})$ was soluble in aqueous alkali and reprecipitated unchanged by acid; only the structures $3\left(\mathrm{R}=\mathrm{SO}_{3} \mathrm{Na}\right)$ and $3(\mathrm{R}=\mathrm{CN})$ will account for this fact. It may be that some reactions of 3 -isothiazolone ${ }^{1}$ will need to be re-interpreted in the light of this result.

Reaction of $1(\mathrm{R}=\mathrm{H})$ with cyanide gave $3(\mathrm{R}=\mathrm{CN})$ directly, accompanied by variable amounts of a higher-melting isomer; this could be obtained from pure 3 $(\mathrm{R}=\mathrm{CN})$ by refluxing in ethanol containing a trace of KCN. It was shown to be the heterocycle (4) by direct comparison with an authentic sample ${ }^{2,3}$.

$\mathbf{1}(\mathrm{R}=\mathrm{H})$ reacts readily with phenylisocyanate, and less smoothly with $\mathrm{KCNO}$, to give $\mathbf{1}(\mathrm{R}=\mathrm{CONHPh})$ and $\mathbf{1}\left(\mathrm{R}=\mathrm{CONH}_{2}\right)$, respectively. This would not be predicted of a compound containing such an acidic $\mathrm{NH}$ group.

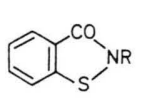

1

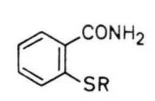

2

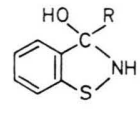

3

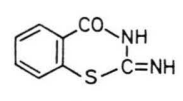

4
Request for reprints should be sent to Dr. W. V. FARRAR, The University of Manchester Institute of Science and Technology, PO Box 88, Manchester M60 1QD, England.

\section{Experimental}

\section{Reaction with $\mathrm{NaHSO}_{3}$}

A mixture of $1(\mathrm{R}=\mathrm{H})(4 \mathrm{~g})$ and aqueous $\mathrm{NaHSO}_{3}(30 \%: 25 \mathrm{ml})$ was stirred at $50{ }^{\circ} \mathrm{C}$ until solution was complete. On cooling to $0{ }^{\circ} \mathrm{C}$ the sodium salt $\left(3, \mathrm{R}=\mathrm{SO}_{3} \mathrm{Na}\right)(5 \mathrm{~g})$ crystallised (platelets from ethanol).

$$
\begin{array}{lllll}
\text { Analysis } & \left(\mathrm{C}_{7} \mathrm{H}_{6} \mathrm{NNaO}_{4} \mathrm{~S}_{2} \cdot \mathrm{H}_{2} \mathrm{O}\right) \\
\text { Found } & \mathrm{C} 31.1 & \mathrm{H} 3.2 & \mathrm{Na} 8.6 & \mathrm{~S} 24.0, \\
\text { Calcd } & \mathrm{C} 30.8 & \mathrm{H} 2.95 & \mathrm{Na} 8.4 & \mathrm{~S} 23.45 .
\end{array}
$$

\section{Reaction with cyanide}

When $1(\mathrm{R}=\mathrm{H})$ was refluxed with aqueousethanolic KCN, two isomeric compounds were formed; one crystallised directly from the reaction mixture, the other was obtained by adding water to the filtrate. The latter was identical with the substance precipitated when the,,bisulphite compound" (above) was treated with aqueous $\mathrm{KCN} .3(\mathrm{R}=\mathrm{CN})$ formed slender needles from aqueous ethanol, m.p. ca. $145^{\circ} \mathrm{C}$ apparently accompanied by dissociation into $\mathbf{1}(\mathrm{R}=\mathrm{H})$ and $\mathrm{HCN}$.

\section{Analysis $\left(\mathrm{C}_{8} \mathrm{H}_{6} \mathrm{~N}_{2} \mathrm{OS}\right)$ \\ Found $\begin{array}{llll}\text { C 54.0 } & \text { H } 3.5 & \text { N } 15.4 & \text { S 17.5, }\end{array}$

Calcd C 53.95 H 3.4 N 15.75 S 18.0.

$3(\mathrm{R}=\mathrm{CN})$ was soluble in $2 \mathrm{~N} \mathrm{NaOH}$, and unchanged by boiling for $1 \mathrm{~h}$; similar treatment with $2 \times \mathrm{HCl}$ gave a neutral substance, m.p. $100-102{ }^{\circ} \mathrm{C}$, identified as diphenyl disulphide $2,2^{\prime}$-dinitrile ${ }^{4}$.

The less soluble isomer (4) formed heavy prisms from much ethanol, m.p. $285-286{ }^{\circ} \mathrm{C}$ after changing to long needles at $c a .260{ }^{\circ} \mathrm{C}$. It did not depress the m.p. of 4 prepared from cyanamide and $o$-thiolbenzoic acid ${ }^{2,3}$.

\section{Analysis}

Found $\quad$ C 53.8 $\quad$ H $3.6 \quad$ N $15.3 \quad$ S 18.3.

\section{Reaction with RCNO}

When equimolecular amounts of $\mathbf{1}(\mathrm{R}=\mathrm{H})$ and $\mathrm{PhNCO}$ were mixed in toluene solution, heat was evolved and $1(\mathrm{R}=\mathrm{CONHPh})$ crystallised in high yield as prisms, m.p. $186-188^{\circ} \mathrm{C}$ (subl.).

Analysis $\left(\mathrm{C}_{14} \mathrm{H}_{10} \mathrm{~N}_{2} \mathrm{O}_{2} \mathrm{~S}\right)$

Found $\quad$ C $62.7 \quad$ H $4.0 \quad$ N $10.3 \quad$ S 11.2,

$\begin{array}{llllll}\text { Calcd } & \text { C } 62.2 & \text { H } 3.7 & \text { N } 10.4 & \text { S } 11.85 .\end{array}$ 